\title{
A T-LIMFOCITÁK BŐRBE VÁNDORLÁSA, A BŐR MINT IMMUNSZERV T-SEJTES HOMEOSZTÁZISA
}

\section{MIGRATION OF T LYMPHOCYTES INTO THE SKIN, T CELL HOMEOSTASIS OF A SKIN}

\author{
Lupsa Nikolett \\ molekuláris biológus, tudományos segédmunkatárs, Semmelweis Egyetem Genetikai, Sejt- és Immunbiológiai Intézet \\ lupsa.nikolett@med.semmelweis-univ.hu
}

\begin{abstract}
ÖSSZEFOGLALÁS
Az emberi szervezet homeosztázisának fenntartásában és a különböző fertőzések elleni védekezésben jelentős szerepe van a szervezetben keringő számos T-sejt- populációnak. Az emberi testben, immunállapotától függetlenül a T-sejtek túlnyomó többsége az immunológiai perifériákon, például a bőrben helyezkedik el. Az ilyen szervi környezetekből a T-sejtek rendszerint nehezen nyerhetők ki, bennük pedig csak nehezen vizsgálhatóak, így számos esetben az ilyen sejtekkel kapcsolatos tudásunk igen korlátozott. Számos bizonyítékkal rendelkezünk arról, hogy a vérben keringő T-sejtek sajátságai, működése, melyeket a vizsgálati célokra leggyakrabban használunk, nem feltétlenül tükrözik a perifériákon elhelyezkedőkét, illetve, hogy a különböző szervekben, szövetekben elhelyezkedő T-sejt alcsoportok számos, egymástól is igen eltérő, csak az adott szervre jellemző funkcióval rendelkeznek. A T-sejtek vándorlása a vér és a perifériás szövetek között mind az egészséges, mind a fertőzés alatt álló szervezetben igen dinamikus folyamat, mely számos receptor-ligand kölcsönhatáson alapszik. Ezek megjelenése a különböző T-sejt-populációkon azok szervezeten belüli elhelyezkedésétől és a sejtek érettségi állapotától függően is dinamikusan változik. A bőr esetében az a receptor-ligand spektrum, amely a szövetbe való belépéshez, az ott tartózkodáshoz vagy a szövet elhagyásához szükséges, intenzív kutatások tárgya, nagy irodalommal rendelkezik, azonban ennek ellenére továbbra is csak igen felületes tudással rendelkezünk róla. Mindez problémát jelent, lévén a bőrbe való vándorlást támogató T-sejtes markerek azonosítása és működésük megértése döntő fontosságú lenne egyes vakcinák fejlesztésében, némely fertőző betegségek kórfolyamatának felderítésében, egyes autoimmun rendellenességek kezelésében és egyes ráktípusok immunterápiájában is. Jelen öszszefoglalóban a legjelentősebb T-sejtes bőr homing markereket mutatjuk be, azok szabályozó faktorait, illetve hatásukat a bőr immunológiai homeosztázisára.
\end{abstract}

\section{ABSTRACT}

A large number of distinct $T$ cell populations circulate in the human body actively maintaining tissue homeostasis by seeking and destroying various pathogens in virtually all human tissues. Regardless of the immunological status of the host, the vast majority of T cells is located in the 
immunological peripheries, such as the skin. There is a large body of evidence suggesting that phenotypical properties of T cells circulating in the blood, typically analysed in most clinical and research settings, do not necessarily reflect to the phenotype and activites of $T$ cells resident in the peripheries. Moreover, $\mathrm{T}$ cell populations present in distinct tissues display remarkably different phenotypes and have rather divergent functions, as well. In both health and disease, migration of human T cells to distinct tissues of the host is a dynamic process regulated by a wide variety of receptor-ligand interactions varying among different $T$ cell populations, different target organs and also different stages of $T$ cell maturation. The process of skin homing (entry into skin, establishing residence in the skin, and egress from the skin) is one of the bestknown T cell homing processes, but is still far from being completely understood. Identification and understanding of molecular markers and processes involved in skin homing is crucial to next generation vaccine development, improved therapeutic control of several infectious diseases, autoimmune disorders and is urgently needed to improve efficacy of some forms of cancer immunotherapy too. Hence, it is not surprising that investigation of T cell homing represent cutting edge research. In this brief review, we summarize the most important T cell skin homing markers, their regulatory factors and effects on skin homeostasis.

Kulcsszavak: bőr, T-sejt homing, markerek, kemokin, integrin, szelektin

Keywords: skin, T cell homing, markers, chemokine, integrin, selectin

T-SEJTEK KIJUTÁSA AZ IMMUNOLÓGIAI PERIFÉRIIÁKRA: ÁLTALÁNOS SZABÁLYOK ÉS MECHANIZMUSOK

A T-sejtek fontos résztvevői a külső kórokozók elleni védekezésnek, amelyhez elengedhetetlenül szükséges a vérkeringés elhagyása és a perifériás szövetekbe történő belépés, vagyis a transzendothéliális migráció.

Ez a migrációs folyamat négy fő lépésre bontható. A folyamat első lépése a lassulás, hiszen a vérkeringéssel utazó immunsejtek túl gyorsan haladnak ahhoz, hogy a vérerek falával kapcsolatba léphessenek, így a $4000 \mu \mathrm{m} / \mathrm{sec}$ sebességükröl $40 \mu \mathrm{m} / \mathrm{sec}$ sebességre kell lassulniuk. A lassulást a sejteken termelődő mucinok, illetve az érfalon termelődő szelektinek kapcsolata teszi lehetővé. Ezt követi a gördülés fázisa, amelynek során a sejt és az érfal egyre közelebb kerül egymáshoz, és a sejt polarizálódik. Itt továbbra is a szelektinek játszák a főszerepet. Ezt követően egy aktivációs lépés során a sejt és az érfal között egyre erősebb kötődés alakul ki, melyben az aktivációs szignálok hatására megjelenő egyre több kemokin és integrin a felelős. A folyamat vége a diapedezis, amikor a sejt két endothél sejt között haladva a véráramból a szövetbe kerül.

A T-sejtek vándorlását a különböző szövetekbe elsősorban a szelektinek, integrinek, kemokinek és azok ligandjai szabályozzák. A legfőbb szelektinek az L, P és E szelektinek, melyek közül az L a naiv T-sejtek felszínén, míg a P és az E változat 
a gyulladt endothélián expresszálódik. A T-sejtek felszínére jellemző P szelektin ligand (PSGL-1) elsősorban a P szelektinnel kapcsolódik, de a másik két szelektinnel is interakcióba léphet. Ezek a kapcsolatok fontos szerepet játszanak a T-sejtek különböző aktivációs szintjein, a különböző perifériás szövetbe való vándorlásban, a transzendothéliás migráció lassulás és gördülés fázisának megvalósításával. Az integrinek sejtfelszíni receptorok, melyek kapcsolódásának erőssége ligandjaikhoz sejtes stimuláció hatására növelhető. Ez a folyamat az úgynevezett inside-out signaling, vagyis a sejt citoplazmájából induló szignalizációs útvonal képes a sejt belseje felöl növelni a felszíni integrin kötési erösségét. Az integrinek is fontos szereplői a transzendothéliális migráció aktivációs, illetve diapedezis lépésének, mely során a sejt nagyon közel kerül az endothéliához. A két legjelentősebb általános kapcsolódási pont a lymphocyte function associated-antigen (LFA-1) és az endothélium/HEV által termelt ICAM-1, illetve a Very Late Antigen-4 (VLA-4) és a Vascular cell adhesion protein 1 (VCAM-1) között lévő kapcsolat.

Az adhéziós molekulák mellett szintén kiemelt jelentőségủ molekulacsoport a kemokinek családja, melynek fő funkciói a kemotaxis indukálása, a sejtek adhéziójának fokozása és effektor leukociták aktiválása. Emberben eddig több mint 50 kemokint és 18 kemokinreceptort azonosítottak. A homeosztatikus kemokinek esetén a gyulladásos ingerek hiányában történik a szabályozás, míg a gyulladásos kemokinek esetén az effektor T-sejtek a gyulladás helyszínére történő toborzása, illetve további gyulladásos kemokinek termelődésének fokozódása figyelhetö meg. Ezek együttesen egy olyan irányítószámot határoznak meg, mely megadja, melyik T-sejt marad a keringésben, melyik léphet be és melyik perifériás szövetbe, illetve melyik vándorolhat a másodlagos nyirokszervekbe. A vándorlás szabályozása három kiemelt területen történik: a) az érhálózat mikrovaszkuláris területein, ahol a sejtek transzendothéliális migrációval elhagyják a véráramot, b) a kemokineket termelö sejteknél, ahol a T-sejtek kapcsolatba léphetnek a célsejtekkel, illetve c) a nyirokrendszernél, ahol a sejtek képesek elhagyni az egészséges vagy gyulladt szövetet. Sajnos a mai napig nagyon keveset tudunk a T-sejtek, illetve azok alcsoportjainak homingjáról és szabályozásáról, illetve kevés olyan markerrel rendelkezünk, amely csak egy szövetbe történő vándorláshoz, illetve csak egy fajta sejttípuson jelenne meg, így specifikálva a különbözö homing folyamatokat (Nolz, 2015).

\section{A BŐRBE VÁNDORLÓ EFFEKTOR T-SEJTEK KIALAKULÁSA}

A bőrbe vándorló T-sejtek kialakulásának folyamata a naiv T-sejtek létrejöttével kezdődik. A naiv T-sejtek az érésük elsődleges helyeként felfogható tímuszból frissen kijutott, érett T-sejtek, melyek még nem találkoztak egy őket aktiváló antigénnel. Ezek a sejtek nagyon kis mennyiségben vagy egyáltalán nem termelnek 
citokineket, és alkalmatlanok a patogénekkel szembeni védekezésre, illetve a perifériás szövetekbe való belépésre. Az ilyen T-sejtek egész testre kiterjedő folyamatos recirkulációt folytatnak a vérerekből a másodlagos nyirokszervekbe, majd a nyirokkeringésen keresztül vissza a vérkeringésbe, melynek egyetlen célja az őket aktiválni képes antigénnel való találkozás. Járőrözésük során folyamatosan keresik a külső környezetből származó, vagyis nem saját és sok esetben veszélyes antigéneket. Ezek az antigének általában egy fertőzést vagy szövetkárosodást követően a bőr felszíni vagy mélyebb rétegeiből a bört felügyelö nyirokcsomókba szállítódnak. A szállításban az úgynevezett antigénprezentáló sejtek, például Langerhans- vagy dendritikus sejtek vesznek részt. Ezek a sejtek gyakran igen nagy sürüségben vannak jelen a bör különböző rétegeiben, és folyamatosan szondázzák a környezetüket, azzal a céllal, hogy ezeket a megjelenő antigéneket beszállítsák a környéki nyirokcsomókba, és bemutassák az oda belépő T-sejteknek (Nolz et al., 2011).

A naiv T-sejtek az antigént prezentáló sejtekkel a nyirokcsomókban találkozva, a megfelelő antigént felismerve és másodlagos kölcsönhatások révén nagyon gyorsan számos osztódást hajtanak végre. Ennek során egyetlen T-sejt akár tízezer utódsejtet is létrehozhat. Ezek az újonnan keletkező sejtek, igaz, rövid életidejüek, ám számos effektor funkcióval rendelkeznek (citokintermelés, citolízis), és naiv társaiktól eltérően elhagyják a keringést, és a különböző szövetekbe vándorolnak, ahol újonnan nyert funkcióik révén részt vesznek a kórokozók elpusztításában. A fertőzés leküzdését követően közelítőleg 90-95\%-uk apoptózissal elpusztul, míg kis hányaduk hosszú életidejủ memóriasejtekké lesz, így biztosítva az újrafertőződés során a még hatékonyabb immunválaszt. A memóriasejtek az előző két csoport, tehát a naiv és effektor sejtek területein, vagyis a nyirokcsomókban (újraaktiválódás miatt), illetve a perifériás szövetekben (azonnali immunitás biztosítása) is megtalálhatóak. A T-sejtek ezen dinamikus változását kíséri a sejtek génexpressziós profiljának változása, amely befolyásolja mozgásukat és szervezeten belüli lokalizációjukat, illetve a lokalizációnak megfelelö változatos funkciókat biztosít a különböző T-sejt-populációknak.

\section{AZ EFFEKTOR T-SEJTEK BŐRBE VALÓ VÁNDORLÁSÁNAK SZABÁLYOZÁSA}

A bör a szervezetünk legnagyobb és leggyorsabban növő szerve, melynek fö feladata a belső szervek fizikai és kémiai stresszfaktorok és behatások elleni védelme, a külső környezetből származó kórokozók elleni barrier-védelem fenntartása, a vízháztartás fenntartása, illetve a börben zajló egyéb összetett élettani folyamatok szabályozása. A külső környezet elsődleges gátjaként a bőr gazdag immunsejtekben, amelyek egymással összetett sejthálózatokat alkotnak, és a bőr rétegeiben elhelyezkedő kiegészítő szervekkel, illetve az extracelluláris mátrixszal 
együttesen hozzák létre a bőr immunrendszerét. Az emberi bőrt két fö rétegre, az epidermiszre és a dermiszre bonthatjuk. Míg az epidermisz egy többrétegü fizikai gát, melyet jórészt differenciálódó keratinociták alkotnak, addig a dermisz egy kollagénszálakban és immunsejtekben gazdag kötőszövet. Az immunsejteloszlás tekintetében a T-sejtek mindkét rétegben előfordulnak, ám a szövetben maradó, illetve recirkuláló T-sejtek többsége az epidermisz és dermisz határán, az úgynevezett dermális-epidermális csomópontokban és a vérerek közelében helyezkednek el. Az antigén- és kostimuláció hatására aktiválódott, most már effektor T-sejtek a nyirokkeringésen keresztül elhagyják a nyirokcsomót, és elvesztik CD62L és CCR7 kemokin expressziójukat, így a továbbiakban már nem tudnak visszatérni a nyirokcsomókba (Cruz et al., 2018).

A kapott szignálok következtében egy teljesen új génexpressziós mintázatot alakítanak ki, beindul a citokintermelésük, majd elindulnak a cél perifériás szövetbe, esetünkben a bőrbe, ahol ténylegesen a fertőzés elleni küzdelem résztvevői lesznek a patogének leküzdésének támogatása, szervezése vagy a patogéneket tartalmazó sejtek lízise, elpusztítása révén. A T-sejtek bőrbe lépéséhez nemcsak a T-sejtek felszíni markerei, de a bőrszövet endothélián megjelenő számos adhéziós (P és E szelektin, ICAM-1, VCAM-1) és gyulladásos kemokinexpressziója is elengedhetetlen. A veleszületett immunitással ellentétben a T-sejtek felszínén nem folyamatos a P és E szelektin ligandok expressziója, így az adhéziós molekulákhoz való kötődésük mindig az adott antigén okozta aktiváció következménye. Ezért is képtelenek a naiv T-sejtek ezen szelektinekhez kapcsolódni, és a perifériás szövetekbe lépni. Számos kemokin leírásra került a bőrbe történő vándorlás kapcsán, ám ezek közül csak kevés mutat szelektív, kizárólag a bőrre jellemző expressziót (1. táblázat).

1. táblázat. A bőrirányú homingot elősegítő legfontosabb adhéziós molekulák és kemokin receptorok

\begin{tabular}{|l|l|l|}
\hline \multicolumn{1}{|c|}{ Szövet } & \multicolumn{1}{|c|}{ T-sejt homing receptor } & \multicolumn{1}{c|}{ Ligand } \\
\hline \multirow{3}{*}{ Bör } & CLA & E/P szelektin \\
\cline { 2 - 3 } & CD43E & E szelektin \\
\cline { 2 - 3 } & VLA-4 $\left(\alpha_{4} \beta_{1}\right)$ & VCAM-1 \\
& LFA-1 $\left(\alpha_{L} \beta_{2}\right)$ & ICAM-1 \\
& CCR4 & CCL17 \\
& CCR10 & CCL27 \\
\hline
\end{tabular}

Az egészséges bőr kétszer annyi T-sejtet tartalmaz, mint a vér, és ezen sejtek 98\%a cutaneous lymphocyte antigen (CLA)-pozitív T-sejt. Ezzel összhangban a CLA 
a bőrbe vándorló T-sejtek talán legfontosabb markere; ez a molekula voltaképpen a P szelektin egy speciálisan glikolizált ligandja, melynek elsődleges funkciója a bőrirányú vándorlást mutató T-sejtek bőrbe való lokalizációja. A CLA, a bőr endothélium által termelt $\mathrm{E}$ szelektinnel való kapcsolódása révén részt vesz a T-sejtek lassulásában és gördülésében az endothélián való átlépés során, ám ezek a kapcsolatok nem kizárólagosan bőrspecifikusak, ami további bőr homing molekulák szerepét feltételezi a folyamatban. Ilyen fontos további kapcsolódási pont a VLA-4, VCAM-1 kapcsolat, mely az általános LFA-1, ICAM-1 interakció mellett a diapedezis lépését segíti elő a bőrbe. További, a bőr homingban szerepet játszó marker, a gyulladásos kemokin CCR4 és ligandja a dermális fibroblasztok által termelt CCL17 közötti kapcsolat. A CCR4 szerepet játszik a vaszkuláris felismerésben, míg ligandja föleg gyulladás során jelenik meg a bőr venuláinak felszínén. A CCR4 expressziója reumatoid artritiszes betegek tüdejében és szinoviális folyadékjában is leírásra került, tehát ez sem kizárólagos bőrhoming-specifikus marker.

A T-sejtek aktivációján túl fontos még megemlíteni a perifériás szövet hatását a homing markerek finomhangolásában is. Ilyen szöveti tényező a $\mathrm{D}_{3}$-vitamin migrációra gyakorolt hatása. A D-vitamin szerepet játszik a szövetben elhelyezkedő dendritikus sejtek (DC) fejlődésének elősegítésében, mely sejtek fontosak a T-sejtek aktivációjában, illetve elösegítik a T-sejtek bőr homing markereinek expresszióját. Az emberi bőrben a napsugárzás hatására termelődik a $\mathrm{D}_{3}$-vitamin előalakja, amely önmagában inaktív, ám a DC-k hatékony közremüködésével aktív formává alakítható, mely elösegíti a CCR10 sejtfelszíni expresszióját. A CCR10 és ligandja az epidermális keratinociták által termelt CCL27 közötti kapcsolat egy újabb bőrirányú vándorlást elösegítő interakció. Összességében tehát elmondható, hogy a bőrbe vándorló T-sejtek fenotípusának kialakítása egy komplex folyamat, amely számos, egymással együttmüködő homing marker megjelenését eredményezi a bőrbe irányított T-sejteken, és azok szoros, integrált együttmüködését igényli a T-sejteknek a bőrbe való sikeres bevándorlásához (McCully-Moser, 2011).

\section{A BŐRBEN TALÁLHATÓ EGYÉB, NEM EFFEKTOR T-SEJTEK CSOPORTJAI}

A bőrben az aktivált effektor T-sejteken túl memóriasejteket is találunk. A memóriasejtek őrzik a kórokozóval való találkozás emlékét, és így egy újrafertőződés során sokkal gyorsabb és hatásosabb immunválaszt képesek kiváltani. Igaz ezek a sejtek hosszú életidejüek, ám korántsem homogének, amit jól tükröz a szervezeten belüli lokalizációjuk, illetve prezentált homingmarker-készletük. A különböző memóriapopulációk elkülönítése számos, a nyirokcsomóba lépéshez szükséges marker (CD62L és CCR7), illetve egyéb, a periférián való megmaradásukhoz nélkülözhetetlen sejtfelszíni molekula (CD69 és $\alpha E \beta 7$ integrin) 
meglétén avagy hiányán alapszik. A bör szempontjából fontos effektor memória (Tem), illetve rezidens memória (Trm) sejteken a CD62L és CCR7 markerek expressziós szintje extrém alacsony marad, e sejtek a nyirokcsomók iránt csekély affinitást mutatnak, és emiatt a perifériás szövetekben fognak koncentrálódni. Mindkét memória-sejttípus a bőr első védelmi vonalát képezi, de míg a CD69-et és $\alpha E \beta 7$ integrint nem hordozó Tem-sejtek fertőzés hatására érkeznek a bőrbe, és a fertőzés leküzdése után képesek visszatérni a véráramba, addig a CD69-re és $\alpha E \beta 7$ integrinre egyaránt pozitív Trm-sejtek, mint nevük is utal rá, rezidensek a bőrben, azaz képtelenek elhagyni a bőrt, és visszatérni a vérkeringésbe. Ennek oka, hogy integrin $\alpha \mathrm{E}$, vagyis CD103 az E kadherinnel lép interakcióba, mely a bőrben az epithél sejtek által termelt tipikus, abundáns sejt-sejt adhéziós molekula. A CD103 kalciumion-függő homodimereket képez, és kitüntetett szerepe van a T-sejteknek a börhöz, az epithélhez történő fizikai kihorgonyzásában. A Trm-sejtek másik fontos markere, a CD69 pedig a T-sejtek S1PR1-receptorának (Sphingosine-1-phosphate receptor 1) degradációjában játszik szerepet. Az S1PR1 fontos szereplöje a T-sejtek nyirokkeringésen keresztüli szövetelhagyásának; a CD69 tehát ennek a folyamatnak a gátlásával segíti elő a Trm-sejtek bőrben tartását (Mann et al., 2012).

\section{KÓROS FOLYAMATOK HATÁSA A T-SEJTEK BŐRBE VÁNDORLÁSÁRA ÉS MÜKÖDÉSÉRE}

Az előzőekben taglalt különböző T-sejt-populációk homing mintázatai az aktivációs szinten, illetve a szervi környezet befolyásán alapultak, feltételezve azt, hogy a T-sejtek beteljesítik funkciójukat, és sikeresen elpusztítják a külső kórokozókat. Előfordul azonban, hogy a kórokozó eliminálása nem könnyủ, így az antigének hosszú időn át jelen vannak a szervezetben, és krónikus fertőzések vagy krónikus gyulladás kialakulásához vezetnek. Ekkor a T-sejtek hosszú időn át vannak kitéve az antigén stimulusnak, mely során kimerülhetnek, citokintermelésük csökkenhet, illetve további antigén-irányított osztódásokra van szükségük a túléléshez.

Ilyen krónikus, bőrt is érintő kórfolyamat lehet például a 2-es típusú cukorbetegség, melynek hátterében a nem megfelelő inzulintermelés vagy normál inzulintermelés mellett fellépő inzulinrezisztencia okozta vércukorszint növekedés áll. A betegségben szenvedőknél gyakoriak a szövődmények, mint például a lassan gyógyuló sebek, mely folyamat korai szakaszában a bőrben található T-sejtek is részt vesznek. A sebgyógyulás első lépése a vérlemezkék aggregációjából keletkező rögképződés, melyet a citokin és kemokin szekréció követ, gyulladásos választ kiváltva, mely az epithél sejtek proliferációjához és a bör barrier helyreállításához vezet. A T-sejtek a sebgyógyulásban citokin, kemokin és növekedési faktor termelésük révén vesznek részt. A betegség során a T-sej- 
tek száma és faktoraik termelése is csökken, így megakasztva a sebgyógyulási folyamatot már a korai fázisban. Ilyen esetekben terápiásan alkalmaznak egyes gyulladáscsökkentő szereket, mint például metformint, amely képes csökkenteni a T-sejtek citokintermelését és javítani az immunválaszokat, illetve szisztémás inzulint, amely képes a bőrben elhelyezkedő T-sejtek differenciálódását is befolyásolni glükózfelvételükön keresztül, így elősegítve a gyorsabb sebgyógyulást.

A 2-es típusú cukorbetegség bőrszövődményeinél jóval gyakoribb krónikus gyulladással járó bőrbetegség a pikkelysömör (pszoriázis). A betegség elterjedése Magyarországon 2\% körüli, és legjellemzőbb tünetei a bőrön megjelenő piros, viszkető bőrelváltozások. A pszoriázis feltételezett kiváltó tényezői között egyaránt találunk környezeti és genetikai tényezőket, ám a T-sejtek szerepe a betegségben kitüntetett. A pszoriázisos bőrléziók kialakulásának hátterében többek között az IL-23/IL-17 citokintengely abnormális szabályozása áll, mely elősegíti a T-sejt differenciációt, a T-sejtek IL-17 termelését és ezzel a CLA+ CD8+ T-sejtek számának növekedését a bőrben. Az IL-17 termelés hatására emellett, pozitív visszacsatolásként, további immunrendszeri sejtek toborzása is történik a bőrbe, így súlyosbítva a betegségre jellemző tüneteket. Az IL-23/IL-17 tengely müködésének helyreállítására jelenleg két monoklonális immunterápia áll rendelkezésre, az ustekinumab, illetve secukinumab kezelés. Az első esetében a T-sejtek felszínén található IL-23 receptor kerül blokkolásra, így csökkentve az IL-17 termelést, míg a secukinumab esetén már a termelődő IL-17 kerül megkötésre, így csökkentve a pozitív visszacsatolást és a gyulladást (McCully-Moser, 2011).

A bőr T-sejtjeinek müködésében hasonló zavarok állnak be egyes autoimmun betegségek, például a foltos hajhullás esetén is, aminek kialakulásában szintén a bőrbe vándorló T-sejtek játsszák a főszerepet. Ebben az esetben is az előbb említett IL-17 gyulladásos axis hatására nagy mennyiségben vándorolnak T-sejtek a bőrbe, megnő IFN-gamma termelésük, és a haj növekedési ciklusának leállításával akadályozzák új hajszálak megjelenését. Emellett a folyamatban a szabályozó, vagyis a regulatórikus T-sejtek csökkenését is látjuk, így a T-sejtek felszaporodása és aktivációja kontroll nélkül mehet végbe. Végezetül, különböző citokinek emelkedett szintje pozitív visszacsatolásként tovább erősíti a T-sejtek IFN-gamma termelését és a gyulladás fenntartását. A betegség kezelésére sajnos elfogadott terápia még nem létezik, ám számos próbálkozást láthatunk a haj növekedésének visszaállítására, általában kortikoszteroidok alkalmazásával. Ezen túlmenően számos monoklonális immunterápia is tesztfázisban van, mint például a mielofibrózis kezelésére már alkalmazott ruxolitinib kezelés tesztelése. A ruxolitinib az IFN-gamma szignalizációt és termelést képes blokkolni, így csökkentve a gyulladást. 


\section{ÖSSZEGZÉS}

A fentieket összefoglalva jól látható, hogy a T-sejtek aktivációs állapota, illetve szervi lokalizációja is markánsan befolyásolja a sejtek sejtfelszíni homing markereinek jelenlétét. A T-sejtek vándorlása a szervezeten belül jól definiálható integrin, szelektin, kemokin molekulák, és ezek ligandjai/receptorai között létrejövő kapcsolatokon keresztül valósul meg, dinamikusan követi az aktivációs szignálok, illetve a szervi lokalizáció és ahhoz kapcsolódó funkció támasztotta igényeket. Számos általános, többféle sejtpopuláción megjelenő, avagy különböző aktiváltsági állapotra jellemző marker található ezen sejtek felszínén, amelyek közül kevés az olyan kizárólagos marker, amely csak egyetlen sejttípuson, vagy csak egyetlen érési állapotra, egyfajta homing folyamatra lenne jellemző. Mindezek következtében a T-sejtek vándorlása során mindig markerkombinációkat mint egyedi markereket kell keresnünk egy-egy szervbe történő migráció során. A homing markerek expressziós mechanizmusának, illetve szabályozásának mielőbbi, mélyebb megértése égető probléma, melynek alaposabb feltárása jelentősen segítené különböző, egyes szervekre korlátozott, T-sejtek-okozta megbetegedések újgenerációs, célzott terápiákkal történő kezelését.

\section{IRODALOM}

Cruz, M. S. - Diamond, A. - Russell, A. et al. (2018): Human $\alpha \beta$ and $\gamma \delta$ T Cells in Skin Immunity and Disease. Frontiers in Immunology, 9, 1304. DOI: 10.3389/fimmu.2018.01304, https://www. ncbi.nlm.nih.gov/pmc/articles/PMC5997830/

Mann, E. R. - Smith, K. M. - Bernardo, D. et al. (2012): Review: Skin and the Immune System. Journal of Clinical \& Experimental Dermatology Research, S-2. DOI: 10.4172/2155-9554.S2003, https://www.longdom.org/open-access/review-skin-and-the-immune-system-2155-9554. S2-003.pdf

McCully, M. L. - Moser, B. (2011): The Human Cutaneous Chemokine System. Frontiers in Immunology, 2, 33. DOI: 10.3389/fimmu.2011.00033, https://www.ncbi.nlm.nih.gov/pmc/articles/ PMC3342080/

Nolz, J. C. (2015): Molecular Mechanisms of CD8+ T cell Trafficking and Localization. Cellular and Molecular Life Sciences, 72, 13, 2461-2473. DOI: 10.1007/s00018-015-1835-0, https:// www.ncbi.nlm.nih.gov/pmc/articles/PMC4458431/

Nolz, J. C. - Starbeck-Miller, G. R. - Harty, J. T. (2011): Naive, Effector and Memory CD8 T-cell Trafficking: Parallels and Distinctions, Immunotherapy, 3, 10, 1223-1233. DOI: 10.2217/ imt.11.100, https://www.ncbi.nlm.nih.gov/pmc/articles/PMC3214994/ 